\title{
Functional Interplay Between Arabidopsis NADPH Oxidases and Heterotrimeric G Protein
}

\author{
Miguel Angel Torres, ${ }^{1,2}$ Jorge Morales,, ${ }^{1,2}$ Clara Sánchez-Rodríguez,, ${ }^{1,2}$ Antonio Molina, ${ }^{1,2}$ and \\ Jeffery L. Dangl $\left.\right|^{3,4}$
}

${ }^{1}$ Centro de Biotecnología y Genómica de Plantas (UPM-INIA), Universidad Politécnica de Madrid, Campus Montegancedo, Autopista M40 Km38, Pozuelo de Alarcón, 28223, Madrid, Spain; ${ }^{2}$ Departamento de Biotecnología, Escuela Superior Técnica de Ingenieros Agrónomos, UPM, Avda. Complutense, 28040, Madrid, Spain; ${ }^{3}$ Department of Biology and Department of Pharmacology, University of North Carolina, Chapel Hill, 32599-3280, U.S.A.; ${ }^{4}$ Howard Hughes Medical Institute, Department of Biology, Department of Microbiology and Immunology, Carolina Center for Genome Sciences, University of North Carolina, Chapel Hill, NC 27599-3280, U.S.A.

Submitted 3 October 2012. Accepted 19 February 2013.

The plant NADPH oxidases produce reactive oxygen species (ROS) in response to pathogens that have diverse functions in different cellular contexts. Distinct phenotypic outcomes may derive from the interaction of NADPH oxidase-dependent ROS with other signaling components that mediate defense activation. We analyze the interaction between NADPH oxidases AtRbohD and AtRbohF and the Arabidopsis heterotrimeric $G$ protein. The $G \beta$ subunit (AGB1) of the heterotrimeric $G$ protein is required for full disease resistance to different Pseudomonas syringae strains. Genetic studies reveal that, upon $P$. syringae infection, $A G B 1$ and $A t R b o h D$ and $A t R b o h F$ can function in the same pathway, as the $a g b 1$ null allele is epistatic to the NADPH oxidase null alleles, combinatorial mutants display the agb1 phenotypes, and $a g b 1$ suppresses some of the atrbohD atrbohF double mutant phenotypes. In contrast, increased susceptibility to the necrotrophic fungus Plectosphaerella cucumerina displayed by agb1 and atrbohD atrbohF is enhanced in the $a g b 1$ atrbohD atrbohF triple mutant, suggesting that NADPH oxidase and heterotrimeric $G$ proteins mediate different response pathways in response to this necrotrophic pathogen. The defense response mediated by $A G B 1$ is independent of pathogen-dependent salicylic acid accumulation and signaling, as the agb1 sid2 (isochorismate synthase 2) double mutant showed enhanced disease susceptibility to $P$. syringae and Plectosphaerella cucumerina as compared with both single mutants. This study exemplifies the complex interplay between signaling events mediating defense activation, depending on the type of plant-pathogen interaction.

The apoplastic production of reactive oxygen species (ROS) is among the fastest events observed ubiquitously in plants after pathogen attack (Lamb and Dixon 1997; Torres et al. 2006).

Current address for C. Sánchez-Rodríguez: Max Planck Institute of Molecular Plant Physiology, Wissenschaftspark Golm, Am Mühlenberg, 14476Potsdam-Golm, Germany.

Corresponding author: M. A. Torres; E-mail: miguelangel.torres@upm.es

* The $\boldsymbol{e}$-Xtra logo stands for "electronic extra" and indicates that six supplementary figures are published online.

C 2013 The American Phytopathological Society
These ROS, mainly the superoxide anion and its dismutated product hydrogen peroxide, are signals that orchestrate many responses, not only in response to pathogens but also to other biotic and abiotic stimuli and to developmental cues (Suzuki et al. 2011).

ROS have different cellular origins. Among these, ROS producing NADPH oxidases located at the cell plasma membrane are key early players in the control of many processes in response to both environmental and developmental stimuli (Suzuki et al. 2011). Plant NADPH oxidases, called RBOH for respiratory burst oxidase homologs, are a family of plasma membrane-localized enzymes with homology to mammalian NADPH NOX proteins (Sumimoto 2008). Arabidopsis contains a multigene family of 10 AtRboh members (Torres and Dangl 2005). Genetic studies revealed that, whereas some RBOH proteins perform specific functions, AtRbohD and AtRbohF can mediate multiple functions in the plant, from pathogen response to abiotic stress signaling, lignification, and stomatal closure, frequently with additive effects (Suzuki et al. 2011).

$\mathrm{RBOH}$ proteins are required for ROS production in response to pathogens, often in association with the hypersensitive response (HR), a type of programmed cell death (Pogany et al. 2009; Torres et al. 2002; Zhang et al. 2007). However, the extracellular superoxide produced by various $\mathrm{RBOH}$ proteins may serve different functions in defense. $\mathrm{RBOH}$ proteins can act as

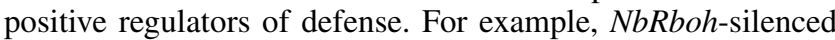
plants displayed suppressed HR and were more susceptible to normally avirulent Phytophthora infestans (Yoshioka et al. 2003), and silencing of barley HvRbohA allowed increased penetration by Blumeria graminis (Trujillo et al. 2006). Also, Arabidopsis AtRbohD and AtRbohF are required for full HR in response to avirulent strains of the bacterium Pseudomonas syringae as well as for callose deposition in response to flg22 (Torres et al. 2002; Zhang et al. 2007). However, the enhanced disease resistance to a weakly virulent strain of the oomycete Hyaloperonospora arabidopsidis observed in atrbohD and atrbohF mutants suggested that $\mathrm{RBOH}$ proteins can function as negative regulators as well (Torres et al. 2002). Additionally, AtRbohD is required for cell death in cells that are damaged by the necrotrophic fungus Alternaria brassicicola, but it simultaneously inhibits cell death in neighboring cells (Pogany et al. 2009). Thus, while the $\mathrm{RBOH}$ proteins are required for pathogen-induced superoxide production, these ROS can apparently function in a context-dependent manner. 
Interactions with other plant defense modulators may account for these context-dependent outcomes. RBOH activation affects different signal transduction pathways, such as calcium signaling, protein phosphorylation and lipid signaling. All plant $\mathrm{RBOH}$ proteins contain EF hands, calcium binding motifs in the N-terminal domain that are necessary for their functionality (Oda et al. 2010; Takeda et al. 2008). Thus, phosphorylation or binding of small Rac GTPases or phospholipase D $\alpha 1$ derived phosphatidic acid to the N-terminal domain of $\mathrm{RBOH}$ activate its oxidase activity (Wong et al. 2007; Zhang et al. 2009). Moreover, RBOH-derived ROS activates calcium channels and the same phosphorylation pathways that mediate RBOH activation (Asai et al. 2008; Zhang et al. 2009).

Additionally, interaction between NADPH oxidases and plant hormone signaling modulates ROS function in defense. ROS interacts in different ways with salicylic acid (SA) signaling. Exogenously applied ROS acts synergistically in a signalamplifying loop with SA to drive HR (Draper 1997; Shirasu et al. 1997). However, ROS produced via AtRbohD antagonizes SA to limit programmed cell death to the site of infection (Torres et al. 2005). Consistent with this observation, negative feedback regulation of SA and ethylene by AtRbohD may inhibit the spread of cell death induced by necrotrophic pathogens (Pogany et al. 2009). Also, coordinated production of ROS and nitric oxide (NO) lead to HR (Delledonne et al. 2001) and both signals act synergistically to regulate abscisic acid (ABA)-induced stomatal closure (Desikan et al. 2008). However, ROS antagonizes NO in basal defense to the necrotrophic pathogen Botrytis cinerea (Asai et al. 2008). ROS signaling is associated with growth regulating hormones such as gibberellin or ABA that can modulate ROS production following infection (Achard et al. 2008; Asselbergh et al. 2007). This interplay may help to fine-tune ROS signals and contribute to the multiplicity of functions of ROS in different plant-pathogen interactions.

Heterotrimeric $\mathrm{G}$ proteins constitute membrane-anchored complexes that couple extracellular signals to downstream effectors that mediate many signal transduction pathways (Temple and Jones 2007). Emerging evidence associates these regulatory proteins with signal transduction pathways mediating many processes in plants, including plant-pathogen interactions (Trusov et al 2010). The canonical G-protein consists of three different units, $\mathrm{G} \alpha, \mathrm{G} \beta$, and $\mathrm{G} \gamma$. Upon activation, the $\mathrm{G} \alpha$ subunit dissociates from the obligate G $\beta \gamma$ dimer to activate downstream elements of the signal transduction pathway (Temple and Jones 2007). Arabidopsis expresses single, canonical G $\alpha$ and $\mathrm{G} \beta$ proteins, and three $\mathrm{G} \gamma$ subunits (Jones and Assmann 2004; Offermanns 2003; Thung et al. 2012; Trusov et al. 2008). Studies with mutants in different subunits of the complex have confirmed their role in defense. For example, analysis of the rice $d$ warfl ( $d 1)$ mutant in the single $\mathrm{G} \alpha$ subunit indicates that $\mathrm{G} \alpha$ is required for full $\mathrm{HR}$ and resistance to avirulent races of the rice blast fungus Magnaporthe grisea (Suharsono et al. 2002). However, in Arabidopsis, mutations in the $\mathrm{G} \alpha$ subunit GPA1 have minor or no effect on response; by contrast, the single canonical $G \beta$ subunit $A G B 1$ is required for resistance to some fungal pathogens (Delgado-Cerezo et al. 2012; Llorente et al. 2005; Trusov et al. 2006, 2009). Thus, the Arabidopsis agbl mutant is more susceptible than wild-type plants to the necrotrophic fungi Botrytis cinerea, Plectosphaerella cucumerina, and Alternaria brassicicola, and to the vascular fungus Fusarium oxysporum. The response of agbl plants to virulent and avirulent isolates of the biotrophic oomycete $H$. arabidopsidis and the bacterium $P$. syringae did not differ from that of wild-type plants (Llorente et al. 2005, Trusov et al. 2006). Thus, the different heterotrimeric $G$ protein subunits can function differently depending on the plant species and the particular plant-pathogen interaction studied. AGB1 residues required for defense have recently been characterized (Jiang et al. 2012), and it has been demonstrated that AGB1 and G $\gamma$ subunits (AGG1 and AGG2) function together, since the $a g b l$ and the agg1 agg2 double mutant display comparable alterations in response to necrotrophic fungal infection (Delgado-Cerezo et al. 2012).

Genetic evidence indicates that heterotrimeric $G$ proteins function with NADPH oxidase-derived ROS in several plant responses to the environment (Chen et al. 2004). High levels of exogenous ozone $\left(\mathrm{O}_{3}\right)$ drive a spatial and a temporal progression of ROS that is similar to the pathogen-induced oxidative burst (Joo et al. 2005). AtRbohD and AtRbohF were implicated in the intercellular signaling and ultimate cell death arising from high levels of $\mathrm{O}_{3}$ exposure (Joo et al. 2005). Interestingly, heterotrimeric $\mathrm{G}$ proteins were shown to control this ROS production and sensitivity to $\mathrm{O}_{3}$. In addition, heterotrimeric $\mathrm{G}$ proteins stimulate ROS production to activate guard-cell calcium channels (Chen et al. 2004). Pharmacological evidence suggests that, during plant defense responses, ROS production by the NADPH oxidases is mediated by heterotrimeric $G$ proteins (Vera-Estrella et al. 1994). And genetic studies in rice showed that OsRacl, a small GTPase involved in the activation of the NADPH oxidase, acts downstream of the G $\alpha$ subunit in response to infection with Magnaporthe grisea (Suharsono et al. 2002). From these various studies, we hypothesized that heterotrimeric $\mathrm{G}$ proteins could interact with RBOH-derived ROS signaling in response to pathogen attack.

To test this hypothesis, we analyzed the defense response of Arabidopsis mutants in NADPH oxidase and in different subunits of the heterotrimeric $G$ protein following challenge with two very different pathogens, either the hemibiotrophic bacterial pathogen $P$. syringae or the necrotrophic fungus strain, Plectosphaerella cucumerina BMM. Our results illustrate the complex relationship between the signals that mediate defense responses in which the relationship between signals varies depending on the type of plant-pathogen interaction.

\section{RESULTS}

agb1 displays increased susceptibility to $P$. syringae.

We examined whether mutants in the Arabidopsis heterotrimeric G protein subunits G $\beta$ (agbl-2) (Ullah et al. 2003) and G $\beta$ (gpal-4) (Jones et al. 2003; Ullah et al. 2001) show differences compared with wild type Col-0 plants in response to the infection with the hemibiotrophic bacteria $P$. syringae pv. tomato DC3000 (Fig. 1A to D). After bacterial inoculation, agbl plants displayed increased chlorotic symptoms (Fig. 1A). These symptoms correlated with enhanced bacterial growth in $a g b l$ as compared with the wild type in response to both the virulent (P. syringae pv. tomato DC3000) and the avirulent $[P$. syringae pv. tomato DC3000(avrRpml) and $P$. syringae pv. tomato DC3000(avrRpt2)] strains (Fig. 1B and C; Supplementary Fig. 1). Moreover, $a g b 1$ displayed enhanced growth of $P$. syringae pv. tomato DC3000hrcC, a strain deficient in the type III secretion system (Fig. 1D). Thus, AGB1 is required for full basal defense against $P$. syringae. On the other hand, gpal displayed the same level of bacterial growth as wild type. Bacterial growth in agbl gpal was similar to that determined in agbl (Fig. 1B and D). Together, these data indicate that $A G B 1$ is required for basal disease resistance to $P$. syringae, whereas GPAl has no effect on bacterial resistance.

We monitored both $\mathrm{H}_{2} \mathrm{O}_{2}$ production and the HR cell death associated with infection by avirulent bacteria. $\mathrm{H}_{2} \mathrm{O}_{2}$ accumulation appeared to be slightly diminished in the $a g b l$ mutant in response to $P$. syringae pv. tomato DC3000(avrRpml) as revealed by diaminobenzidine (DAB) staining (Supplementary 

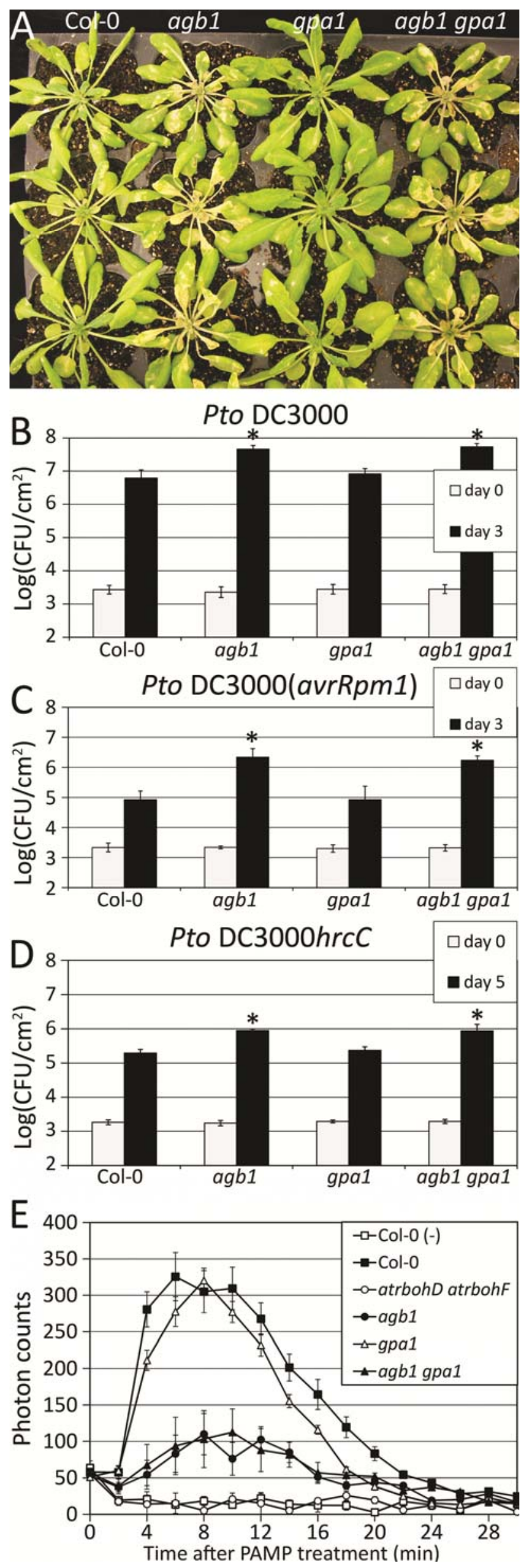

Fig. 2A). Similarly, $a g b 1$ displayed a reduction of DAB stain after infection with $P$. syringae pv. tomato DC3000hrcC. To quantify the apparent reduction of ROS production in $a g b 1$, we monitored $\mathrm{H}_{2} \mathrm{O}_{2}$ production in response to flg22, the elicitoractive epitope of bacterial flagellin (Felix et al. 1999). Luminol assays following treatment with $100 \mathrm{nM}$ flg22 confirmed that the production of total $\mathrm{H}_{2} \mathrm{O}_{2}$ in $a g b$ l was significantly reduced compared with that determined in Col-0 wild-type plants (Fig. 1E; Supplementary Fig. 3), as previously reported (Ishikawa 2009; Jiang et al. 2012). The double NADPH oxidase mutant atrbohD atrbohF fully abolished this ROS production (Fig. 1E). On the other hand, $\mathrm{H}_{2} \mathrm{O}_{2}$ accumulation in the heterotrimeric $\mathrm{G}$ protein mutants was not altered after infection with the necrotrophic fungus Plectosphaerella cucumerina (Llorente et al. 2005). Thus, AGB1 is required for full $\mathrm{H}_{2} \mathrm{O}_{2}$ production in response to hemibiotrophic bacteria but has no obvious effect on ROS produced in response to necrotrophic fungi. In addition, cell death after inoculation with $P$. syringae pv. tomato DC3000(avrRpml), monitored by trypan blue staining, was not affected in these mutants. Thus, Arabidopsis heterotrimeric $\mathrm{G}$ proteins have no obvious effect on cell death occurring in response to pathogens, but AGB1 is required for full ROS accumulation in response to pathogen-associated molecular patterns (PAMPs) like flg22. Our data contrast previous reports of responses to acute ozone treatment (Joo et al. 2005), where Rboh-dependent ROS production and cell death is compromised in gpal but not in agbl.

We also examined the response of $a g b 1$, gpal, and $a g b 1$ gpal to infection with the biotrophic oomycete $H$. arabidopsidis. No differences were observed in disease susceptibility between these heterotrimeric $\mathrm{G}$ protein mutants and Col- $0 \mathrm{wt}$ plants in response to virulent (Noco2) or avirulent (Cala2, Emco5) $\mathrm{H}$. arabidopsidis isolates (Fig. 2A; Supplementary Fig. 4). Also, $\mathrm{H}_{2} \mathrm{O}_{2}$ production and cell death, monitored by DAB and trypan blue stains, respectively, were unaffected in these lines in response to $H$. arabidopsidis (data not shown).

\section{agb1 suppresses some pathogen-associated phenotypes} displayed by atrbohD atrbohF .

Epistasis analyses between the heterotrimeric $\mathrm{G}$ protein null alleles gpal and $a g b 1$ and the combined NADPH oxidase null alleles atrbohD and atrbohF showed that, late in development, the dwarf phenotype of atrbohD atrbohF was partially restored to wild type in agbl atrbohD atrbohF (Fig. 2B). The atrbohD atrbohF plants displayed reduced HR in response to avirulent P. syringae pv. tomato DC3000(avrRpm1) and enhanced HR and disease resistance in response to a virulent $H$. arabidopsidis isolate (Torres et al. 2002). We found that $a g b l$ restored to wild-type levels the defective HR of atrbohD atrbohF in response to avirulent $P$. syringae pv. tomato DC3000(avrRpm1), as upon inoculation the conductivity (a measurement of ion

Fig. 1. Susceptibility is enhanced in the agblmutant in response to Pseudomonas syringae. A, Symptoms on 4.5-week-old plants of the genotypes listed, 5 days after spray inoculation with a $5 \times 10^{7} \mathrm{CFU} \mathrm{ml} \mathrm{m}^{-1}$ concentration of $P$. syringae pv. tomato DC3000. B to D, Quantification of bacterial growth on the heterotrimeric $\mathrm{G}$ protein mutants after injection with $10^{5} \mathrm{CFU} \mathrm{ml^{-1 }}$ concentrations of the virulent bacterial strain P. syringae pv. tomato DC3000, the isogenic avirulent strain $P$. syringae pv. tomato DC3000(avrRpm1), or the type III secretion mutant $P$. syringae pv. tomato DC3000hrcC, respectively. Values represent the mean \pm standard error (SE) of four replicates. Asterisks indicate significant differences compared with wild-type Col-0 $(P<$ 0.01 , analysis of variance). Experiments were repeated three times with similar results. $\mathbf{E}, \mathrm{H}_{2} \mathrm{O}_{2}$ production measured in a luminol-based assay using leaf discs from plants of the listed genotypes after treatment with $100 \mathrm{nM}$ flg22 (except Col-0 ( - ) untreated). Values are means \pm SE $(n=16)$. The experiment was repeated three times with similar results. 
leakage correlated with HR) was similar in agbl atrbohD atrbohF and wild-type plants (Fig. 2C). agbl also abolished the enhanced disease resistance to the $H$. arabidopsidis isolate Emco5 in the atrbohD atrbohF background (Fig. 2A). By contrast, gpal did not affect the atrbohD atrbohF phenotypes. As expected, the agbl gpal atrbohD atrbohF quadruple mutant exhibited the same phenotypes as agbl atrbohD atrbohF (Fig. $2 \mathrm{~A}$ to $\mathrm{C}$ ). Thus, $a g b 1$ suppresses the pathogen response phenotypes displayed by atrbohD atrbohF.
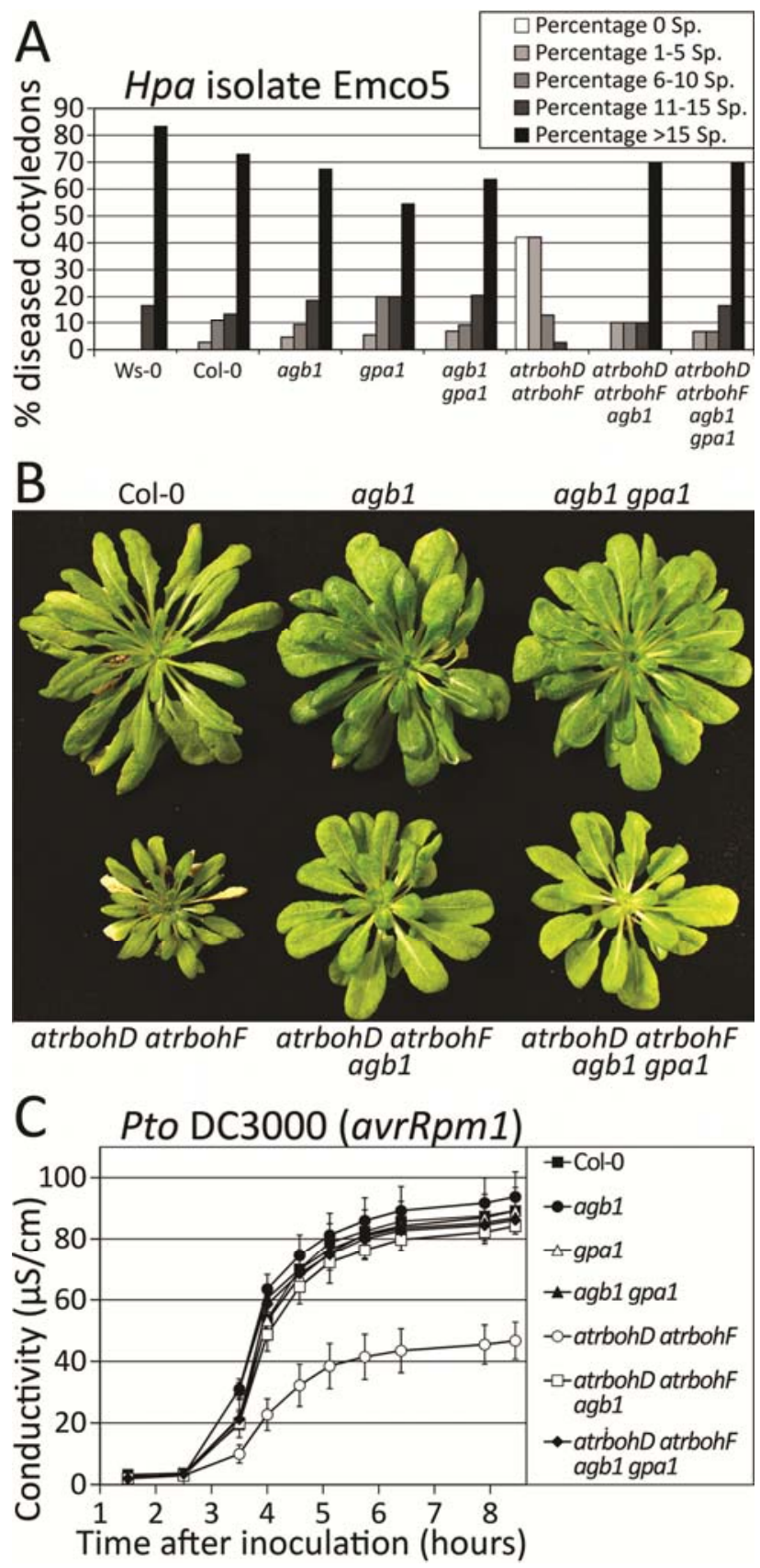

Fig. 2. agb1 suppresses atrbohD atrbohF phenotypes. A, 10-day-old seedlings were inoculated with $5 \times 10^{-4} \mathrm{ml}^{-1}$ sporangia of Hyaloperonospora arabidopsidis isolate Emco5. Sporangiophore (Sp) production was quantified at 5 days postinoculation on 40 to 80 cotyledons per genotype. B, Representative 6-week-old plants of the indicated genotypes. C, Conductivity measurement after injection of 4-week-old plants with $2.5 \times 10^{7}$ $\mathrm{CFU} \mathrm{ml}{ }^{-1}$ of the avirulent strain $P$. syringae DC3000(avrRpm1). Data represented are means and standard error of conductivity $\left(\mu \mathrm{S} \mathrm{cm}^{-1}\right)$ calculated from $6 \mathrm{ml}$ of water containing four leaf discs (four repetitions per genotype) over time. Experiments were repeated three times with similar results.
Of note, the enhanced susceptibility of agbl to $P$. syringae pv. tomato DC3000 was not altered in the atrbohD atrbohF mutant background (Fig. 3). Similarly, the quadruple mutant agbl gpal atrbohD atrbohF also displayed, like agbl, enhanced bacterial growth and chlorotic symptoms after $P$. syringae pv. tomato D3000 and P. syringae pv. tomato DC3000hrcC infection (Fig. 3). Thus, the $a g b l$ phenotype is epistatic to atrbohD atrbohF in response to $P$. syringae infection.

\section{$A G B 1$ and the NADPH oxidases act independently}

to control resistance

to the necrotrophic fungus $\boldsymbol{P}$. cucumerina.

$A G B 1$ is required for full disease resistance to the necrotrophic fungus Plectosphaerella cucumerina (Delgado-Cerezo et al. 2012; Llorente et al. 2005). We sprayed spores of this

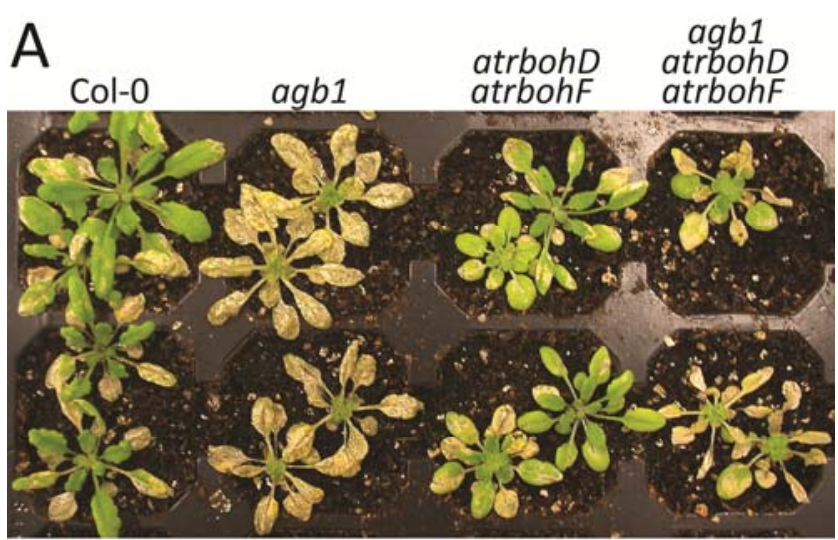

B
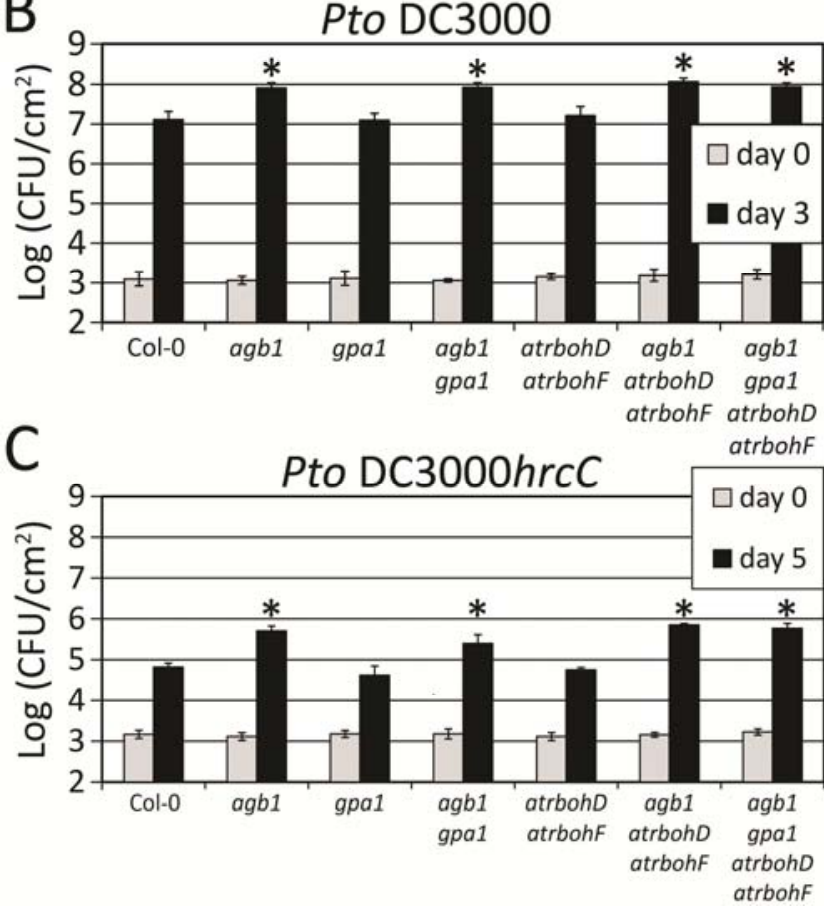

Fig. 3. $a g b 1$ is epistatic to atrbohD atrbohF with respect to Pseudomonas syringae disease phenotypes. A, Symptoms of 4.5 -week-old plants of the indicated genotypes, 8 days after spray inoculation with a $5 \times 10^{7} \mathrm{CFU}$ $\mathrm{ml}^{-1}$ concentration of $P$. syringae pv. tomato DC3000. B and C, Quantification of bacterial growth on 4.5-week-old plants after hand inoculation with concentrations of $10^{5} \mathrm{CFU} \mathrm{ml}{ }^{-1}$ of the virulent bacterial strain $P$. syringae pv. tomato DC3000 and the type III secretion mutant $P$. syringae pv. tomato DC3000hrcC, respectively. Values are means \pm standard error (SE) calculated from four repetitions. Asterisks indicate significant differences compared with wild-type Col- $0(P<0.01$, analysis of variance). Experiments were repeated three times with similar results. 
fungus on the atrbohD atrbohF mutant, on the heterotrimeric $\mathrm{G}$ protein mutants (agbl, gpal, and agbl gpal) and on the combinatorial mutants. Analysis of the symptoms and quantification of the fungal biomass by quantitative polymerase chain reaction (qPCR) showed that atrbohD atrbohF were, like agbl, more susceptible to this fungus than the wild type (Fig. 4; Supplementary Fig. 5). Interestingly, agbl atrbohD atrbohF displayed increased susceptibility compared with either $a g b l$ or atrbohD atrbohF. This result indicates that AtRbohD, AtRbohF, and $A G B 1$ are all required for full resistance to Plectosphaerella cucumerina and act independently. Thus, contrary to what we observed in response to the hemibiotrophic bacterial pathogen $P$. syringae pv. tomato DC3000 (Figs. 1 to 3), the NADPH oxidase and the heterotrimeric $G$ protein complex act independently to control basal defense in response to Plectosphaerella cucumerina infection.

\section{Enhanced disease resistance mediated by $A G B 1$ is independent of SA signaling.}

SA mediates many defense responses to biotrophic and hemibiotrophic pathogens. However, SA can antagonize or synergize with AtRboh function, depending on the context (Torres 2010). To assess the role of SA in the defense pathways mediated by the heterotrimeric $G$ proteins and the

\section{A}
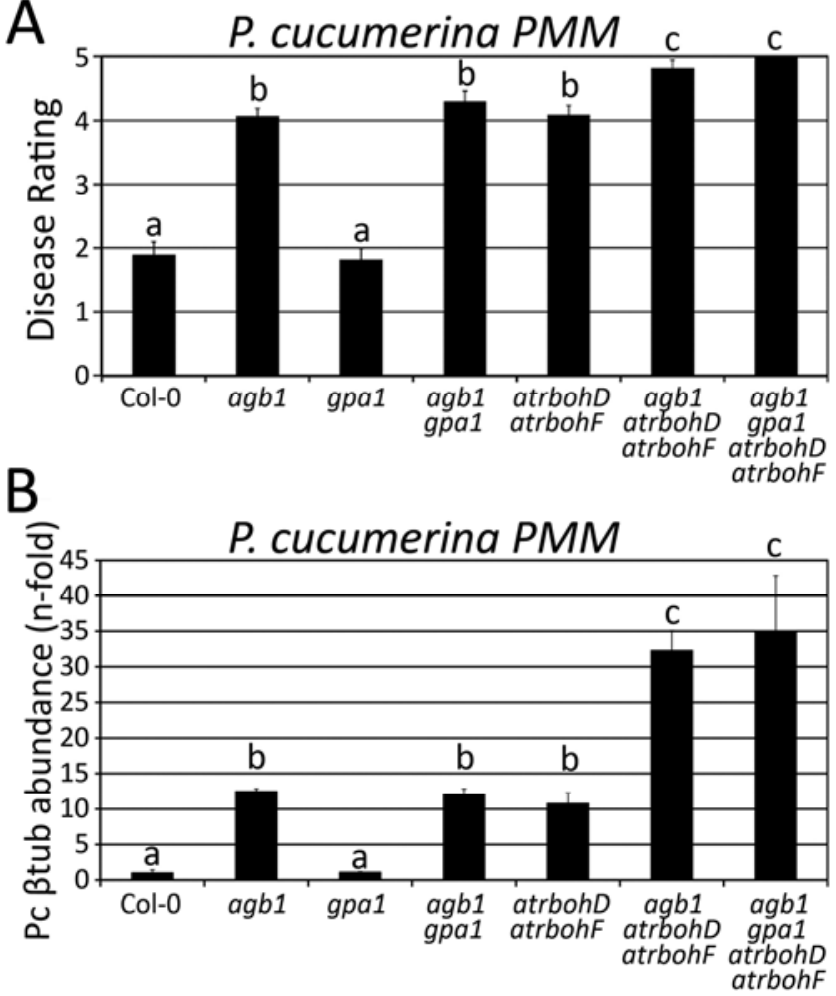

Fig. 4. $a g b 1$ and $a t r b o h D$ atrbohF display additive disease susceptibility to the necrotrophic fungus Plectosphaerella cucumerina. A, Average disease rating ( \pm standard error $[\mathrm{SE}]) 7$ days after spray inoculation with $P$. cucumerina: 1 = no symtoms; $2=$ one chlorotic or necrotic leaf; $3=$ two to three necrotic leaves; $4=$ more than three leaves necrotic; $5=$ plant dead Data comes from one representative experiment out of three experiments carried out with at least 25 plants for each genotype. Letters indicate significant differences between classes at $P<0.01$. B, Quantification of $P$. cucumerina biomass 3 days postinoculation by quantitative polymerase chain reaction analysis. Primers specific for $\beta$-tubulin from the fungus and ubiquitin from Arabidopsis were used. Values are representative as $n$-fold increased expression compared with wild-type Col-0. Data are the means $( \pm \mathrm{SE})$ of three replicates. Statistical analyses were performed using analysis of variance $5 \%$, corrected with Bonferroni test. Letters indicate significant differences. The experiment was repeated three times with similar results.
NADPH oxidase, we obtained combinatorial mutants between $a g b 1$, atrbohD, atrbohF, and the sid2/eds 16 mutant, which is impaired in the isochorismate synthase 2 gene encoding a key SA biosynthetic enzyme (Wildermuth et al. 2001). Infection of these lines with virulent $P$. syringae pv. tomato DC3000 and DC3000hrcC revealed that the double mutant agbl sid2 displayed an increased susceptibility compared with both individual mutants, as measured by both disease symptoms and bacterial growth assays (Fig. 5A to $\mathrm{C}$ ). This result indicates that heterotrimeric $\mathrm{G}$ proteins and $\mathrm{SA}$ act independently in basal defense to $P$. syringae. In contrast, the atrbohD atrbohF sid2 mutant displayed the sid 2 enhanced disease susceptibility phenotype (Fig. 5A to C).

We inoculated, with Plectosphaerella cucumerina spores, $a g b 1$, atrbohD atrbohF, sid2, and combinatory lines, monitored disease symptoms, and quantified the fungal biomass by qPCR (Fig. 5D and E). Although the sid2 mutant exhibited only a slight increase in susceptibility compared with Col-0, the double $a g b 1$ sid 2 displayed a large increased susceptibility compared with the individual mutants. The susceptibility of $a g b l$ sid2 to Plectosphaerella cucumerina was higher than that observed in the agbl atrbohD atrbohF (Fig. 5D and E). These results suggest that heterotrimeric $\mathrm{G}$ proteins and SA act independently in defense against Plectosphaerella cucumerina. The triple atrbohD atrbohF sid2 showed no increased disease susceptibility above that expressed by atrbohD atrbohF, suggesting that AtRboh-derived ROS and SA accumulation act in the same pathway (Fig. 5D and E).

\section{DISCUSSION}

\section{The G $\beta$ subunit of heterotrimeric G protein AGB1} mediates basal resistance to $P$. syringae.

The interaction of ROS with diverse signaling components may explain the multiple physiological responses that they mediate. The Arabidopsis NADPH oxidases AtRbohD and AtRbohF account for the extracellular ROS produced in response to pathogens. Here, we explored whether ROS produced by these NADPH oxidases interacted with the heterotrimeric $G$ protein in the response to different pathogens. Previous studies indicated that the $G \beta$ subunit of the heterotrimeric $G$ protein AGB1 is important for resistance to several fungi, including the necrotroph Plectosphaerella cucumerina (Delgado-Cerezo et al. 2012; Llorente et al. 2005; Trusov et al. 2006, 2009). We have extended the relevance of AGB1 in modulating Arabidopsis resistance to pathogens by demonstrating that $A G B 1$ also contributes to basal defense to the bacterium $P$. syringae pv. tomato DC3000. The agbl plants inoculated either by infiltration or by spray with different $P$. syringae pv. tomato DC3000 strains clearly showed increased bacterial growth and disease symptoms compared with those determined in wild-type plants (Figs. 1, 3, and 5). Previous studies reported no alterations of bacterial growth in the same $a g b l$ mutant allele after syringe inoculation with either virulent (DC3000) or avirulent (JL1065) strains of $P$. syringae (Trusov et al. 2006). We cannot rule out that these contradictory results could be due to slight differences in the experimental conditions that we used in comparison with those described previously (Trusov et al. 2006). However, the enhanced susceptibility of $a g b l$ mutant was corroborated in agbl gpal, which was as susceptible as $a g b l$ to all the $P$. syringae pv. tomato DC3000 strains tested, including DC3000hrcC (Figs. 1, 3, and 5), further demonstrating that $A G B 1$ contributes to basal defense to this bacterial pathogen. In line with our data, it has been previously shown that $A G B 1$ is also required for defense response against Agrobacterium tumefaciens (Ishikawa 2009), suggesting it mediates a common mechanism of response to infection by bacteria in 
addition to necrotrophic and vascular fungi (Delgado-Cerezo et al. 2012; Llorente et al. 2005; Trusov et al. 2006, 2009). On the other hand and as previously noted (Llorente et al. 2005), we observed no differences between the heterotrimeric $\mathrm{G}$ protein mutants and wild-type plants in response to the biotrophic oomycete $H$. arabidopsidis. Thus, AGBl mediates defense responses to many but not all pathogens.

Our finding that agbl gpal displayed the same enhanced disease susceptibility to $P$. syringae pv. tomato and Plectosphaerella cucumerina as agbl further implies that $A G B 1$ is critical for the regulation of Arabidopsis defensive response to pathogens (Delgado-Cerezo et al. 2012; Trusov et al. 2006). However, in rice, $\mathrm{G} \alpha$ was implicated in response to infection with the rice blast fungus $M$. grisea, as the rice $d 1$ mutant, defective in the $G \alpha$ subunit, displayed reduced HR and modest loss of resistance to avirulent rice blast (Suharsono et al. 2002). Interestingly, $A G B 1$, but not GPA1, functions in Arabidopsis non-host resistance to the rice blast fungal pathogen $M$. oryzae (Maeda et al. 2009; Nakao et al. 2011). A double mutant impaired in PEN2, encoding a glycosyl hydroxylase involved in nonhost resistance (Lipka et al. 2005), and $A G B 1$ supported significantly increased penetration by this rice pathogen than the pen 2 plants, defective in nonhost resistance (Maeda et al. 2009; Nakao et al. 2011). Thus, although plants possess canonical $G \alpha$ and $G \beta$ subunits, the role of these subunits in defense may be different, depending on the plant species or the pathogen being studied. The diverse functions of these subunits may be accomplished by interaction with different downstream proteins in various contexts, as revealed by the interactome of the Arabidopsis heterotrimeric G proteins (Klopffleisch et al. 2011).

\section{Heterotrimeric G proteins, ROS production, and cell death.}

In the Arabidopsis agbl mutant the production of NADPH oxidase-dependent $\mathrm{H}_{2} \mathrm{O}_{2}$ upon inoculation with $P$. syringae or treatment with the PAMP flg22 was severely compromised (Fig. 1E), whereas $\mathrm{H}_{2} \mathrm{O}_{2}$ production (determined by DAB staining) in response to Plectosphaerella cucumerina or H. arabidopsidis infection was similar to that in wild-type plants, as previously described (Llorente et al. 2005). These data suggest that the Arabidopsis AGB1 protein is required for the full oxidative burst in response to some pathogens, such as $P$. syringae bacteria, whereas it does not control $\mathrm{H}_{2} \mathrm{O}_{2}$ production in response to other pathogens, particularly necrotrophic fungi. This contrasts with the requirement of the rice $\mathrm{G} \alpha$ subunit for ROS production in response to rice blast fungus (Suharsono et al. 2002). Activation of heterotrimeric $G$ proteins requires the dissociation of the $\mathrm{G} \alpha$ and the $\mathrm{G} \beta \gamma$ subunits (Temple and Jones 2007). Accordingly, Arabidopsis G $\beta$ AGB1 forms an obligate dimer with either one of the Arabidopsis $\mathrm{G} \gamma$ subunits ( $\gamma 1 /$ AGG1, $\gamma 2 / A G G 2$, or $\gamma 3 /$ AGG3). Thus, the $\mathrm{G} \beta$ and $\mathrm{G} \gamma 1+\gamma 2$ subunits were shown to function in the control of Arabidopsis immune responses (Delgado-Cerezo et al. 2012; Jiang et al. 2012). In line with this hypothesis, we found that the production of ROS upon flg22 treatment was compromised in agg 1 agg2 whereas, in either aggl or agg2, the level of ROS production was comparable to wild-type plants (Supplementary Fig. 6). Remarkably, ROS production impairment in aggl agg2 was similar to that observed in atrbohD atrbohF, disproving any significant contribution of $A G G 3$ to flg22-mediated ROS production. These results demonstrate that the G $\beta \gamma 1+\gamma 2$ heterodimer constitute the active complex that regulates ROS production, and are in line with the preeminent contribution of these subunits to the regulation of Arabidopsis innate immunity. These data also suggest that heterotrimeric $G$ proteins could function downstream of some pattern recognition receptors, such as the flg22 receptor FLS2. In line with this hypoth- esis, a recent study reports that silencing of both $\mathrm{G} \alpha$ and $\mathrm{G} \beta$ subunits in Nicotiana benthamiana affects defense responses regulated by several microbial elicitors (Zhang et al. 2012).

In our studies, infected gpal plants display wild-type accumulation of $\mathrm{H}_{2} \mathrm{O}_{2}$ (Fig. 1E). This is intriguing because the same gpal-4 mutant allele used in our experiments failed to activate ROS generation by NADPH oxidases in response to high levels of exogenous ozone (Joo et al. 2005). Thus, the interaction of heterotrimeric $\mathrm{G}$ protein signaling and ROS production can also vary depending on the stress. G $\beta \gamma$ downstream signaling would have a more preeminent role on regulating pathogen-induced ROS, whereas G $\alpha$ downstream signaling could regulate ROS production in response to abiotitc stresses. In the heterotrimeric $\mathrm{G}$ protein mutants tested, we did not observed alterations in cell death, monitored either quantitatively (via conductivity assays) or qualitatively (via trypan blue staining) (Fig. 2). These results are in contrast to those reported following high levels of exogenous ozone or in the response to rice blast (Joo et al. 2005; Suharsono et al. 2002). However, the fact that impairment of $A G B 1$ restored cell death levels in the atrbohD atrbohF mutant after inoculation with avirulent bacteria (Fig 2B) indicates that AGB1 can be a negative regulator of cell death in certain situations. Again, these data suggest that heterotrimeric $\mathrm{G}$ proteins can perform different signaling roles leading to cell death in different cellular contexts.

\section{Interaction between AGB1 and NADPH oxidase signaling.}

Our epistasis analysis prompts us to suggest that $A G B 1$ works in the same pathway as NAPDH oxidases AtRbohD and AtRbohF after $P$. syringae and $H$. arabidopsidis infection, since the phenotypes displayed by atrbohD atrbohF are suppressed in atrbohD atrbohF agbl (Fig. 2). The impairment of $A G B 1$ restored to wild-type levels the reduced cell death in response to avirulent $P$. syringae pv. tomato displayed by atrbohD atrbohF and reduced the enhanced cell death and disease resistance response to virulent $H$. arabidopsidis displayed by atrbohD atrbohF. Moreover, atrbohD atrbohF agbl displayed the same enhanced susceptibility to virulent $P$. syringae pv. tomato as agbl (Fig. 3). The fact that agbl displays reduced levels of ROS production in response to flg22 could indicate that the AGB1/AGG1-AGG2 heterodimer works in concert with NADPH oxidases in some contexts to regulate ROS production. This is consistent with the situation in rice in response to $M$. grisea infection. Since ROS production is abolished in $d l$ mutants, and since expression of a constitutive active form of OsRacl restored ROS production, OsRacl likely functions downstream of $\mathrm{G} \alpha$ in ROS production (Suharsono et al. 2002). Interestingly, other phenotypes, such as dwarfing or pathogenesis-related protein expression in response to the $M$. grisea elicitor, were not restored in rice $d l$ plants by expressing active $O s R a c 1$, indicating that the NADPH oxidase does not operate in all the pathways in which $\mathrm{G} \alpha$ is involved.

$A G B 1$ and NADPH oxidase can also work in different resistance pathways. We found that NADPH oxidases have a role in resistance to the necrotrophic fungus Plectosphaerella cucumerina, since atrbohD atrbohF displayed enhanced susceptibility to this pathogen, but this function is independent of AGB1, since agbl atrbohD atrbohF plants showed an enhanced susceptibility to this fungal necrotroph compared with the individual mutants (Fig. 4). Thus, NADPH oxidases and AGB1 have additional, independent functions in response to Plectosphaerella cucumerina. NADPH oxidase function has been linked to SA signaling, although synergism and antagonism has been observed in different cases (Torres 2010). However, we found that heterotrimeric $\mathrm{G}$ protein (AGB1) and SA signaling mediate independent responses against Plectosphaerella cucumerina and $P$. syringae pv. tomato (Fig. 5). Similarly, AGB1-mediated 

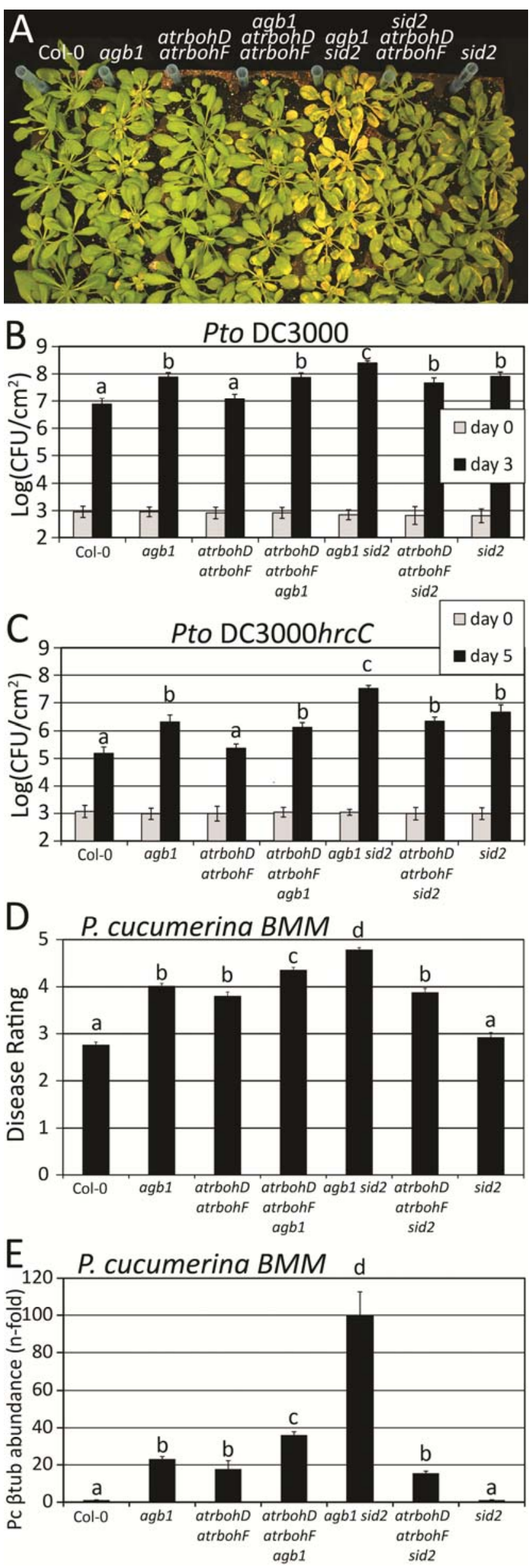

responses against other necrotrophs such as Fusarium oxysporum and Alternaria brassicicola were described to be SAindependent (Trusov et al. 2006, 2009).

Our results indicate a complex relationship between the signaling roles of ROS produced by NADPH oxidase and the heterotrimeric $G$ proteins, in which the functional interaction between these regulatory systems varies depending of the type of pathogen. This diversity of function may be based on the complexity of multiple, specific interactions of the $G$ protein subunits with potential signaling components that exist in plants and that are different from interactors and effectors present in other metazoans (Klopffleisch et al. 2011). The characterization of these downstream components will ultimately contribute to clarification of the complex interaction between NADPH oxidases and heterotrimeric G proteins as they function in various responses to pathogens of diverse lifestyles.

\section{MATERIALS AND METHODS}

\section{Arabidopsis plants and growth conditions.}

Arabidopsis thaliana accession Col-0 and mutants derived from it were grown on a soil/vermiculite 3:1 mixture under a 10-h day and 14-h night schedule, with a daytime temperature of $24^{\circ} \mathrm{C}$ and a night temperature of $22^{\circ} \mathrm{C}$, under relative humidity of $65 \%$ and light intensity of $120 \mu \mathrm{E} \mathrm{m}^{-2} \mathrm{~s}^{-1}$. The mutant lines used in this study were atrbohD and atrbohF (Torres et al. 2002), agb1 (agb1-2) (Ullah et al. 2003), gpal (gpal-4) (Jones et al. 2003), aggl and agg2 (aggl-1 and agg2-1, respectively) (Trusov et al. 2008), and sid2 (eds 16-1) (Wildermuth et al. 2001). Mutant combinations were generated by standard genetic crosses followed by the identification of homozygous mutant alleles by PCR (primers and conditions upon request).

\section{Bacterial inoculation.}

Bacterial strains used in this study were $P$. syringae pv. tomato DC3000, DC3000(avrRpm1), DC3000(avrRpt2), and DC3000hrcC. Four-week-old plants were inoculated using a 1-ml syringe (Debener et al. 1991) or were sprayed with a 0.1 optical density bacterial solution following standard procedures (Zipfel et al. 2004).

Conductivity measurements were performed as described (Torres et al. 2002). Four-week-old plants were injected with $2.5 \times 10^{7} \mathrm{CFU} \mathrm{ml}{ }^{-1}$ of the avirulent P. syringae strain DC3000 (avrRpml) in $10 \mathrm{ml} \mathrm{MgCl}_{2}$. Ten minutes after injection, 7.5$\mathrm{mm}$-diameter leaf discs were collected from the injected area and were washed extensively with water for $50 \mathrm{~min}$. Then,

Fig. 5. agb1 sid2 displays enhanced disease susceptibility compared with the individual mutants. A, Symptoms of 4.5 -week-old plants, 5 days after spray inoculation with a concentration of $5 \times 10^{7} \mathrm{CFU} \mathrm{ml}^{-1}$ of Pseudomonas syringae pv. tomato DC3000. B and C, Quantification of bacterial growth on 4.5-week-old plants after spray inoculation with concentrations of $5 \times 10^{7} \mathrm{CFU} \mathrm{ml}{ }^{-1}$ of the virulent bacterial strain P. syringae pv. tomato DC3000 and the type III secretion mutant $P$. syringae pv. tomato DC3000hrcC, respectively. Values are means \pm standard error (SE) calculated from four repetitions. Letters indicate significant differences at $P<$ 0.01 . D, Average disease rating ( \pm SE) 7 days after spray inoculation with a concentration of $P$. cucumerina $\left(4 \times 10^{6}\right.$ spores per milliliter $)$. Data derived from one representative experiment out of three experiments carried out with at least 30 plants for each genotype. Letters indicate significant differences between classes at $P<0.05$. E, Quantification of $P$. сисиmerina biomass 3 days postinoculation by quantitative polymerase chain reaction analysis. Primers specific for fungal $\beta$-tubulin and Arabidopsis ubiquitin were used. Values are representative as $n$-fold increased expression compared with wild-type Col-0. Data are the average ( \pm SE) of three replicates. Statistical analyses were performed using analysis of variance $5 \%$, corrected with Bonferroni test. Letters indicate significant differences. Experiments were repeated three times with similar results. 
four discs were placed in a tube with $6 \mathrm{ml}$ of water. Four replicates were taken per genotype. Conductivity measurements were taken from the tubes over time with an Orion (Boston) conductivity meter, model 130 . The units of this measurement are microsiemens per centimeter $\left(\mu \mathrm{S} \mathrm{cm}^{-1}\right)$.

\section{Fungal and oomycete inoculation assays.}

Sporangia from $H$. arabidopsidis isolates Emco5, Cala2, and Noco 2 were suspended in water $\left(5 \times 10^{4}\right.$ spores $\left.\mathrm{ml}^{-1}\right)$ and were sprayed on 10-day-old seedlings (Dangl et al. 1992). Inoculated plants were kept under a sealed lid to achieve high relative humidity, and sporangiophores were counted on cotyledons at 5 days postinoculation (dpi) (Emco5) or 7 dpi (Cala2, Noco2).

Spore suspensions $\left(4 \times 10^{6}\right.$ spores $\left.\mathrm{ml}^{-1}\right)$ from Plectosphaerella cucumerina BMM were sprayed on three-week-old plants. Subsequently, plants were kept under high relative humidity. Disease progression was estimated according to HernandezBlanco and associates (2007), by determining the average disease rating value: $1=$ no symptoms; $2=$ one chlorotic or necrotic leaf; $3=$ two to three necrotic leaves; $4=$ more than three leaves necrotic; $5=$ plant dead. Relative quantification of fungal DNA was performed by qPCR with primers specific for $\beta$-tubulin from the fungus and ubiquitin from Arabidopsis as described (Sanchez-Rodriguez et al. 2009).

\section{Histology.}

To visualize $\mathrm{H}_{2} \mathrm{O}_{2}$ in situ, 3,3'-diaminobenzidine (Sigma, St. Louis) staining was performed on Arabidopsis plants after pathogen inoculation as described (Torres et al. 2002). Inoculated leaves were vacuum infiltrated with a $1-\mathrm{mg} \mathrm{ml}^{-1}$ DAB solution. Subsequently, leaves were placed in a plastic box under high humidity until brown precipitate was observed ( 5 to $6 \mathrm{~h}$ ) and were then fixed with a solution of $3: 1: 1$ ethanol/lactic acid/glycerol.

Dead cells were visualized by boiling leaves in lactophenoltrypan blue, followed by destaining in saturated chloral hydrate as described (Slusarenko et al. 1991).

\section{$\mathrm{H}_{2} \mathrm{O}_{2}$ measurements.}

Leaf discs ( $5 \mathrm{~mm}$ diameter; $\mathrm{n}=16$ ) were collected from fully expanded leaves from 4-week-old plants and were washed overnight with $150 \mathrm{ml}$ of water. For $\mathrm{H}_{2} \mathrm{O}_{2}$ measurement, water was exchanged for a solution containing $10 \mu \mathrm{g}$ horseradish peroxidase per milliliter (Sigma) and $100 \mu \mathrm{M}$ luminol (Sigma). $\mathrm{H}_{2} \mathrm{O}_{2}$ production was triggered with $100 \mathrm{nM}$ flg22. Luminescence was measured as relative light units with a TECAN Genius Pro luminescence reader over a period of 40 min. $\mathrm{All}_{2} \mathrm{O}_{2}$ measurements were repeated three times with similar results.

\section{Statistical analyses.}

Statistical differences among Arabidopsis genotypes were determined by one-way analysis of variance and Bonferroni post hoc test, as previously reported (Sanchez-Rodriguez et al. 2009).

\section{ACKNOWLEDGMENTS}

This work was supported by funding from the United States National Science Foundation (IOS-0639964) to J. L. Dangl, by Grant BIO2007-66806 from the Spanish Ministerio de Ciencia e Innovación (MICINN), and Grant (2007)D/562971 from the International Reintegration Program from the European Union to M. A. Torres, and Grant BIO2009-07161 (MICINN) to A. Molina. J. Morales is a recipient of doctoral fellowship from Universidad Politécnica de Madrid. J. L. Dangl is a Howard Hughes Medical InstituteGordon and Betty Moore Foundation Plant Scientist Investigator. We thank P. Epple (University of North Carolina) for useful discussions and critical reading and comments on the manuscript. We thank A. M. Jones for initiating the project with M. A. Torres at the University of North Carolina.

\section{LITERATURE CITED}

Achard, P., Renou, J.-P., Richard Berthomé, R., Harberd, N. P., and Genschik, P. 2008. Plant DELLAs restrain growth and promote survival of adversity by reducing the levels of reactive oxygen species. Curr. Biol. 18:656-660.

Asai, S., Ohta, K., and Yoshioka, H. 2008. MAPK signaling regulates nitric oxide and NADPH oxidase-dependent oxidative bursts in Nicotiana benthamiana. Plant Cell 20:1390-1406.

Asselbergh, B., Curvers, K., Franca, S. C., Audenaert, K., Vuylsteke, M., Van Breusegem, F., and Hofte, M. 2007. Resistance to Botrytis cinerea in sitiens, an abscisic acid-deficient tomato mutant, involves timely production of hydrogen peroxide and cell wall modifications in the epidermis. Plant Physiol. 144:1863-1877.

Chen, Y. L., Huang, R., Xiao, Y. M., Lu, P., Chen, J., and Wang, X. C. 2004. Extracellular calmodulin-induced stomatal closure is mediated by heterotrimeric $\mathrm{G}$ protein and $\mathrm{H}_{2} \mathrm{O}_{2}$. Plant Physiol. 136:4096-4103.

Dangl, J. L., Holub, E., Debener, T., Lehnackers, H., Ritter, C., and Crute, I. R. 1992. Genetic definition of loci involved in Arabidopsis-pathogen interactions. Pages 393-418 in: Methods in Arabidopsis Research. C. Koncz, N.-H. Chua, and J. Schell, eds. World Scientific, Singapore.

Debener, T., Lehnackers, H., Arnold, M., and Dangl, J. L. 1991. Identification and molecular mapping of a single Arabidopsis thaliana locus determining resistance to a phytopathogenic Pseudomonas syringae isolate. Plant J. 1:289-302.

Delgado-Cerezo, M., Sanchez-Rodriguez, C., Escudero, V., Miedes, E., Fernandez, P. V., Jorda, L., Hernandez-Blanco, C., Sanchez-Vallet, A., Bednarek, P., Schulze-Lefert, P., Somerville, S. C., Estevez, J. M., Persson, S., and Molina, A. 2012. Arabidopsis heterotrimeric G-protein regulates cell wall defense and resistance to necrotrophic fungi. Mol. Plant 5:98-114.

Delledonne, M., Zeier, J., Marocco, A., and Lamb, C. J. 2001. Signal interactions between nitric oxide and reactive oxygen intermediates in the plant hypersensitive disease resistance response. Proc. Natl. Acad. Sci. U.S.A. 98:13454-13459.

Desikan, R., Horák, J., Chaban, C., Mira-Rodado, V., Witthöft, J., Elgass, K., Grefen, C., Cheung, M.-K., Meixner, A., Hooley. R., Neill, S. Hancock, J., and Harter, K. 2008. The histidine kinase AHK5 integrates endogenous and environmental signals in Arabidopsis guard cells. PLoS ONE 3:e2491. Published online.

Draper, J. 1997. Salicylate, superoxide synthesis and cell suicide in plant defense. Trends Plant Sci. 2:162-165.

Felix, G., Duran, J. D., Volko, S., and Boller, T. 1999. Plants have a sensitive perception system for the most conserved domain of bacterial flagellin. Plant J. 18:265-276.

Hernández-Blanco, C., Feng, D. X., Hu, J., Sánchez-Vallet, A., Deslandes, L., Llorente, F., Berrocal-Lobo, M., Keller, H., Barlet, X., SánchezRodríguez, C., Anderson, L. K., Somerville, S., Marco, Y., and Molina, A. 2007. Impairment of cellulose synthases required for Arabidopsis secondary cell wall formation enhances disease resistance. Plant Cell 19:890-903.

Ishikawa, A. 2009. The Arabidopsis G-protein $\beta$-subunit is required for defense response against Agrobacterium tumefaciens. Biosci. Biotechnol. Biochem. 73:47-52.

Jiang, K., Frick-Cheng, A., Trusov, Y., Delgado-Cerezo, M., Rosenthal, D. M., Lorek, J., Panstruga, R., Booker, F. L., Botella, J. R., Molina, A. Ort, D. R., and Jones, A. M. 2012. Dissecting Arabidopsis $G-\beta$ signal transduction on the protein surface. Plant Physiol. 159:975-983.

Jones, A. M., and Assmann, S. M. 2004. Plants: The latest model system for G-protein research. EMBO (Eur. Mol. Biol. Organ.) Rep. 5:572-578.

Jones, A. M., Ecker, J. R., and Chen, J.-G. 2003. A reevaluation of the role of the heterotrimeric $\mathrm{G}$ protein in coupling light responses in Arabidopsis. Plant Physiol. 131:1623-1627.

Joo, J. H., Wang, S., Chen, J. G., Jones, A. M., and Fedoroff, N. V. 2005. Different signaling and cell death roles of heterotrimeric $\mathrm{G}$ protein $\alpha$ and $\beta$ subunits in the Arabidopsis oxidative stress response to ozone. Plant Cell 17:957-970.

Klopffleisch, K., Phan, N., Augustin, K., Bayne, R. S., Booker, K. S., Botella, J. R., Carpita, N. C., Carr, T., Chen, J.-G., Cooke, T. R., FrickCheng, A., Friedman, E. J., Fulk, B., Hahn, M. G., Jiang, K., Jorda, L., Kruppe, L., Liu, C., Lorek, J., McCann, M. C., Molina, A., Moriyama, E. N., Mukhtar, M. S., Mudgil, Y., Pattathil, S., Schwarz, J., Seta, S., Tan, M., Temp, U., Trusov, Y., Urano, D., Welter, B., Yang, J., Panstruga, R., Uhrig, J. F., and Jones, A. M. 2011. Arabidopsis G-protein interactome reveals connections to cell wall carbohydrates and morphogenesis. Mol. Syst. Biol. 7:532

Lamb, C., and Dixon, R. A. 1997. The oxidative burst in plant disease resistance. Annu. Rev. Plant Physiol. Plant Mol. Biol. 48:251-275.

Lipka, V., Dittgen, J., Bednarek, P., Bhat, R., Wiermer, M., Stein, M., Landtag, J., Brandt, W., Rosahl, S., Scheel, D., Llorente, F., Molina, A. 
Parker, J., Somerville, S, and Schulze-Lefert, P. 2005. Pre- and postinvasion defenses both contribute to nonhost resistance in Arabidopsis. Science 310:1180-1183.

Llorente, F., Alonso-Blanco, C., Sanchez-Rodriguez, C., Jorda, L., and Molina, A. 2005. ERECTA receptor-like kinase and heterotrimeric G protein from Arabidopsis are required for resistance to the necrotrophic fungus Plectosphaerella cucumerina. Plant J. 43:165-180.

Maeda, K., Houjyou, Y., Komatsu, T., Hori, H., Kodaira, T., and Ishikawa, A. 2009. AGB1 and PMR5 Contribute to PEN2-Mediated Preinvasion Resistance to Magnaporthe oryzae in Arabidopsis thaliana. Mol. PlantMicrobe Interact. 22:1331-1340.

Nakao, M., Nakamura, R., Kita, K., Inukai, R., and Ishikawa, A. 2011. Non-host resistance to penetration and hyphal growth of Magnaporthe oryzae in Arabidopsis. Sci. Rep. 1:171.

Oda, T., Hashimoto, H., Kuwabara, N., Akashi, S., Hayashi, K., Kojima, C., Wong, H. L., Kawasaki, T., Shimamoto, K., Sato, M., and Shimizu, T. 2010. Structure of the N-terminal regulatory domain of a plant NADPH oxidase and its functional implications. J. Biol. Chem. 285:1435-1445.

Offermanns, S. 2003. G-proteins as transducers in transmembrane signalling. Prog. Biophys. Mol. Biol. 83:101-130.

Pogany, M., von Rad, U., Grun, S., Dongo, A., Pintye, A., Simoneau, P., Bahnweg, G., Kiss, L., Barna, B., and Durner, J. 2009. Dual roles of reactive oxygen species and NADPH oxidase RBOHD in an ArabidopsisAlternaria pathosystem. Plant Physiol. 151:1459-1475.

Sanchez-Rodriguez, C., Estevez, J. M., Llorente, F., Hernadez-Blanco, C., Jorda, L., Pagan, I., Berrocal, M., Marco, Y., Somerville, S., and Molina, A. 2009. The ERECTA receptor-like kinase regulates cell wall-mediated resistance to pathogens in Arabidopsis thaliana. Mol. Plant-Microbe Interact. 22:953-963.

Shirasu, K., Nakajima, H., Rajasekhar, V. K., Dixon, R. A., and Lamb, C. J. 1997. Salicylic acid potentiates an agonist-dependent gain control that amplifies pathogen signals in the activation of defense mechanisms. Plant Cell 9:261-270.

Slusarenko, A. J., Croft, K. P., and Voisey, C. R. 1991. Biochemical and molecular events in the hypersensitive response of bean to Pseudomonas syringae pv. phaseolicola. Pages 126-146 in: Biochemistry and Molecular Biology of Host-Pathogen Interactions. C. J. Smith, ed. Oxford University Press, Oxford.

Suharsono, U., Fujisawa, Y., Kawasaki, T., Iwasaki, Y., Satoh, H., and Shimamoto, K. 2002. The heterotrimeric G protein alpha subunit acts upstream of the small GTPase Rac in disease resistance of rice. Proc. Natl. Acad. Sci. U.S.A. 99:13307-13312.

Sumimoto, H. 2008. Structure, regulation and evolution of Nox-family NADPH oxidases that produce reactive oxygen species. FEBS (Fed. Eur. Biochem. Soc.) J. 275:3249-3277.

Suzuki, N., Miller, G., Morales, J., Shulaev, V., Torres, M. A., and Mittler, R. 2011. Respiratory burst oxidases: The engines of ROS signaling. Curr. Opin. Plant Biol. 14:691-699.

Takeda, S., Gapper, C., Kaya, H., Bell, E., Kuchitsu, K., and Dolan, L. 2008. Local positive feedback regulation determines cell shape in root hair cells. Science 319:1241-1244.

Temple, B. R. S., and Jones, A. M. 2007. The plant heterotrimeric G-protein complex. Ann. Rev. Plant Biol. 58:249-266.

Thung, L., Trusov, Y., Chakravorty, D., and Botella, J. R. 2012. G $\gamma 1+\mathrm{G}$ $\gamma 2+\mathrm{G} \gamma 3=\mathrm{G} \beta$ : The search for heterotrimeric G-protein $\gamma$ subunits in Arabidopsis is over. J. Plant Physiol. 169:542-545.

Torres, M. A. 2010. ROS in biotic interactions. Physiol. Plant. 138:414429.

Torres, M. A., and Dangl, J. L. 2005. Functions of the respiratory burst oxidase in biotic interactions, abiotic stress and development. Curr. Opin. Plant Biol. 8:397-403.

Torres, M. A., Dangl, J. L., and Jones, J. D. 2002. Arabidopsis gp91 ${ }^{\text {phox }}$ homologues AtrbohD and AtrbohF are required for accumulation of reactive oxygen intermediates in the plant defense response. Proc. Natl.
Acad. Sci. U.S.A. 99:517-522.

Torres, M. A., Jones, J. D., and Dangl, J. L. 2005. Pathogen-induced, NADPH oxidase-derived reactive oxygen intermediates suppress spread of cell death in Arabidopsis thaliana. Nat. Genet. 37:1130-1134.

Torres, M. A., Jones, J. D. G., and Dangl, J. L. 2006. Reactive oxygen species signaling in response to pathogens. Plant Physiol. 141:373-378.

Trujillo, M., Altschmied, L., Schweizer, P., Kogel, K. H., and Huckelhoven, R. 2006. Respiratory burst oxidase homologue A of barley contributes to penetration by the powdery mildew fungus Blumeria graminis $\mathrm{f}$. $\mathrm{sp}$. hordei. J. Exp. Bot. 57:3781-3791.

Trusov, Y., Rookes, J. E., Chakravorty, D., Armour, D., Schenk, P. M., and Botella, J. R. 2006. Heterotrimeric G proteins facilitate Arabidopsis resistance to necrotrophic pathogens and are involved in jasmonate signaling. Plant Physiol. 140:210-220.

Trusov, Y., Zhang, W., Assmann, S. M., and Botella, J. R. 2008. G $\gamma 1+$ G $\gamma 2$ not equal G $\beta$ : Heterotrimeric $G$ protein $G \gamma a$-deficient mutants do not recapitulate all phenotypes of G $\beta$-deficient mutants. Plant Physiol. 147:636-649.

Trusov, Y., Sewelam, N., Rookes, J. E., Kunkel, M., Nowak, E., Schenk, P. M., and Botella, J. R. 2009. Heterotrimeric G proteins-mediated resistance to necrotrophic pathogens includes mechanisms independent of salicylic acid-, jasmonic acid/ethylene- and abscisic acid-mediated defense signaling. Plant J. 58:69-81.

Trusov, Y., Jorda, L., Molina, A., and Botella, J. R. 2010. G proteins and plant innate immunity. Pages 221-250 in: Integrated G Proteins Signaling In Plants, Signaling and Communication Series. S. Yalovsky, F Baluska, and A. Jones, eds. Springer, Berlin.

Ullah, H., Chen, J.-G., Young, J. C., Im, K.-H., Sussman, M. R., and Jones, A. M. 2001. Modulation of cell proliferation by heterotrimeric G protein in Arabidopsis. Science 292:2066-2069.

Ullah, H., Chen, J. G., Temple, B., Boyes, D. C., Alonso, J. M., Davis, K. R., Ecker, J. R., and Jones, A. M. 2003. The $\beta$-subunit of the Arabidopsis $\mathrm{G}$ protein negatively regulates auxin-induced cell division and affects multiple developmental processes. Plant Cell 15:393-409.

Vera-Estrella, R., Higgins, V. J., and Blumwald, E. 1994. Plant defense response to fungal pathogens. II. G-protein-mediated changes in host plasma membrane redox reactions. Plant Physiol. 106:97-102.

Wildermuth, M. C., Dewdney, J., Wu, G., and Ausubel, F. M. 2001. Isochorismate synthase is required to synthesize salicylic acid for plant defence. Nature 414:562-565.

Wong, H. L., Pinontoan, R., Hayashi, K., Tabata, R., Yaeno, T., Hasegawa, K., Kojima, C., Yoshioka, H., Iba, K., Kawasaki, T., and Shimamoto, K. 2007. Regulation of rice NADPH oxidase by binding of Rac GTPase to its N-terminal extension. Plant Cell 19:4022-4034.

Yoshioka, H., Numata, N., Nakajima, K., Katou, S., Kawakita, K., Rowland, O., Jones, J. D., and Doke, N. 2003. Nicotiana benthamiana gp91 ${ }^{\text {phox }}$ homologs $N$ brbohA and $N$ brbohB participate in $\mathrm{H}_{2} \mathrm{O}_{2}$ accumulation and resistance to Phytophthora infestans. Plant Cell 15:706-718.

Zhang, J., Shao, F., Li, Y., Cui, H., Chen, L., Li, H., Zou, Y., Long, C., Lan, L., Chai, J., Chen, S., Tang, X., and Zhou, J.-M. 2007. A Pseudomonas syringae effector inactivates MAPKs to suppress PAMP-induced immunity in plants. Cell Host Microbe 1:175-185.

Zhang, Y., Zhu, H., Zhang, Q., Li, M., Yan, M., Wang, R., Wang, L., Welti, R., Zhang, W., and Wang, X.C. 2009. Phospholipase D $\alpha 1$ and phosphatidic acid regulate NADPH oxidase activity and production of reactive oxygen species in ABA-mediated stomatal closure in Arabidopsis. Plant Cell 21:2357-2377.

Zhang, H.,Wang, M., Wang, W., Li, D., Huang, Q., Wang, Y., Zheng, X., and Zhang, Z. 2012. Silencing of $G$ proteins uncovers diversified plant responses when challenged by three elicitors in Nicotiana benthamiana. Plant Cell Environ. 35: 72-85.

Zipfel, C., Robatzek, S., Navarro, L., Oakeley, E. J., Jones, J. D., Felix, G., and Boller, T. 2004. Bacterial disease resistance in Arabidopsis through flagellin perception. Nature 428:764-767. 